\title{
Effect of nitrogen source on the levels of nitrate reductase in the yeast Hansenula anomala
}

\author{
Celedonio González and José M. Siverio*
}

Departamento de Bioquimica y Biologia Molecular, Universidad de La Laguna, E-38206 La Laguna, Tenerife, Canarias, Spain

(Received 16 December 1991; revised 27 March 1992; accepted 3 April 1992)

\begin{abstract}
Levels of nitrate reductase (NR) protein in Hansenula anomala and Hansenula wingei were determined using specific antiserum raised against the enzyme from $H$. anomala. Extracts from nitrate-grown cells contained NR protein, while in those from cells grown on ammonium, glutamine or peptone, no cross-reacting material could be observed. Enzyme activity correlated with the levels of cross-reacting material. When nitrate was used as nitrogen source, NR was always present, even in cultures with ammonium, glutamine or peptone, although in these cases both the levels of activity and protein were lower. NR activity was consistently two to four times higher in cells grown in glucose than in cells grown in ethanol. Nitrate was required for NR induction, and deprivation of nitrate from nitrate-grown cells resulted in a rapid loss of NR activity.
\end{abstract}

\section{Introduction}

Some yeasts, such as Hansenula anomala, are able to use nitrate as nitrogen source (Barnett et al., 1984). The main points of regulation in the nitrate assimilatory pathway appear to be the nitrate uptake system and the nitrate reductase (NR). In contrast with the situation for filamentous fungi (Pateman \& Kinghorn, 1976; DunnColeman et al., 1984; Wray \& Kinghorn, 1989), the regulation of NR by nitrogen and carbon sources has been little studied in yeast. So far (Ali \& Hipkin, 1985, 1986; Cannons et al., 1986; Jones et al., 1987; Hipkin, 1989) it has been shown that NR appears in cells cultured in nitrate-containing media and is absent in ammoniumcultured cells.

Several questions remain unanswered concerning the regulation of NR in yeast. It is not clear whether nitrate is an inducer and the reduced nitrogen sources are repressors (nitrogen metabolite repression) or if both mechanisms are operative, and whether the carbon sources also play a role in the regulation of activity levels. In addition, the possible existence of mechanisms that could inactivate NR reversibly or irreversibly has not been carefully examined.

* Author for correspondence. Fax (22) 253344.

Abbreviations: NR, nitrate reductase; YNB, yeast nitrogen base without amino acids and ammmonium sulphate.
In this work we show that in H. anomala, nitrate is an inducer of NR, while the role of nitrogen metabolite repression is unimportant. Effects of nitrate deprivation and glucose are also described.

\section{Methods}

Organism and growth conditions. Hansenula anomala (CECT 1112) was obtained from the Colección Española de Cultivos Tipo (Valencia, Spain). Hansenula wingei (CBS 2432) and Hansenula polymorpha (CBS 4732) were kind gifts from J. A. Barnett (Norwich, England). The yeasts were grown at $28^{\circ} \mathrm{C}$ with shaking in a liquid medium containing $0.17 \%$ yeast nitrogen base without amino acids and ammonium sulphate (YNB, Difco), $2 \%(w / v)$ glucose or ethanol as carbon source, and either $50 \mathrm{~mm}$-sodium nitrate, $50 \mathrm{~mm}$-ammonium chloride, $25 \mathrm{mM}$ glutamine or $2 \%(\mathrm{w} / \mathrm{v})$ Bacto peptone (Difco) as sole nitrogen source.

Preparation of cell-free extracts and NR assay. The cells were stored at $-20{ }^{\circ} \mathrm{C}$ until used. Approximately $50 \mathrm{mg}$ of cells (wet weight) were mixed with $200 \mu \mathrm{l}$ extraction buffer ( $100 \mathrm{mM}$-potassium phosphate, pH 7.4, $20 \mu \mathrm{m}$-FAD, 1 mM-EDTA and $1 \mathrm{mM}$-PMSF) and $1 \mathrm{~g}$ glass beads $(0.5 \mathrm{~mm}$ diameter) and vortexed for $90 \mathrm{~s}$. After $3 \mathrm{~min}$ on ice, $300 \mu \mathrm{l}$ extraction buffer were added, and the mixture was vortexed again for $10 \mathrm{~s}$. The mixture was then centrifuged for $5 \mathrm{~min}$ at $3000 \mathrm{~g}$, and the supernatant used for assay. NR was assayed in a final volume of $1 \mathrm{ml}$, containing $50 \mathrm{~mm}$-potassium phosphate buffer, $\mathrm{pH} \mathrm{7.4,50 \mu \textrm {l }}$ extract (approximately $0 \cdot 10-0.15 \mathrm{mg}$ protein), $20 \mathrm{~mm}$-sodium nitrate and $0.2 \mathrm{~mm}-\mathrm{NADPH}$, plus $10 \mathrm{~mm}$-potassium sulphite as nitrite reductase inhibitor. The assay mixture was incubated at $30^{\circ} \mathrm{C}$ for $15 \mathrm{~min}$, and the reaction stopped with $100 \mu \mathrm{l} 1 \mathrm{M}$-sodium hydroxide and $100 \mu 1 \mathrm{l}$ M-zinc sulphate. The mixture was centrifuged at $3000 \mathrm{~g}$ for $5 \mathrm{~min}$ and nitrite was determined in the supernatant (Snell \& Snell, 1949). 
(a)

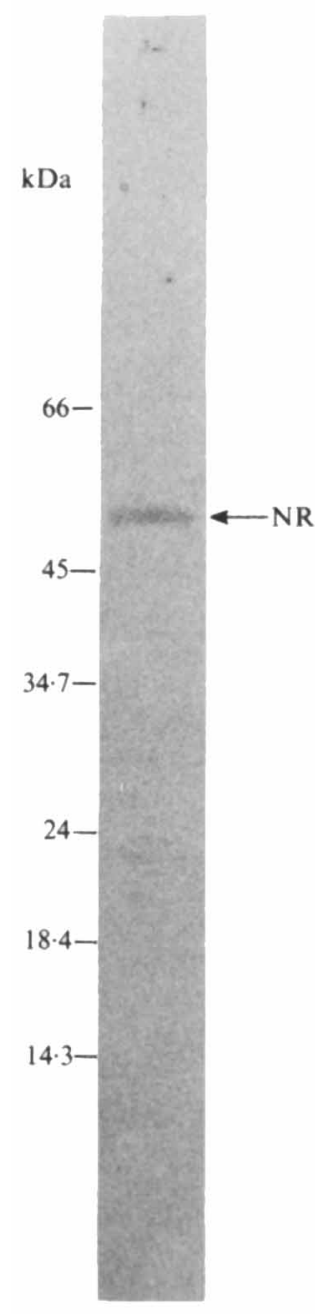

(b)

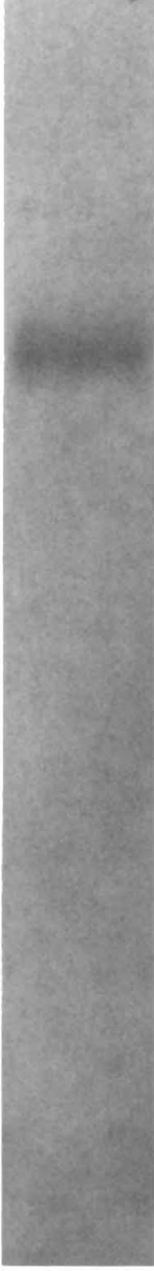

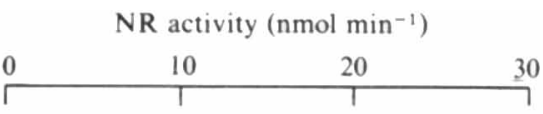

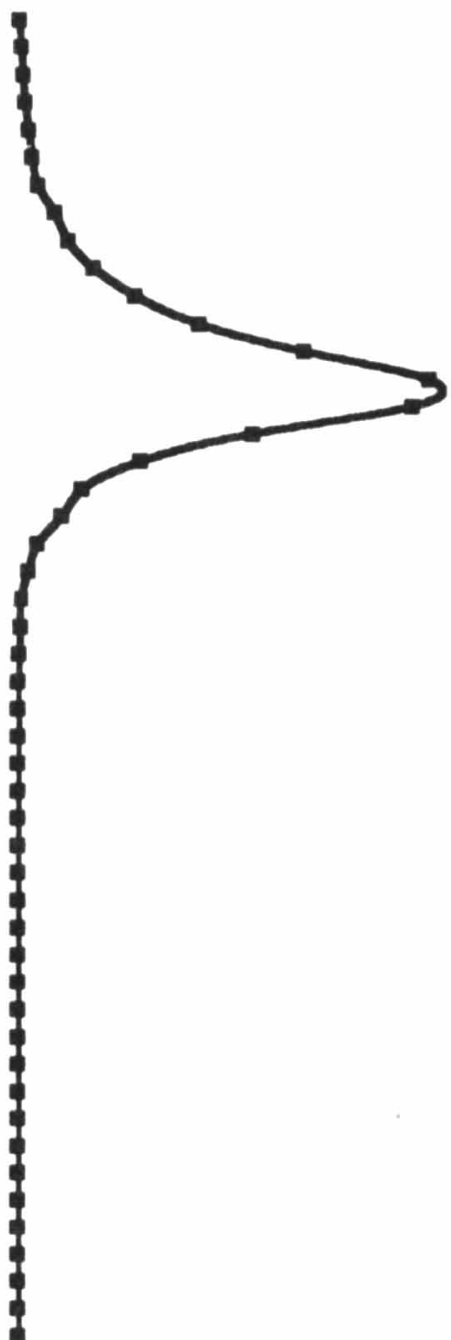

Fig. 1. Specificity of anti-NR antiserum. (a) Crude extract, $10 \mu \mathrm{g}$ protein from nitrate-grown cells subjected to SDS-PAGE and transferred to nitrocellulose. NR was determined on the nitrocellulose filter with 1:2000 anti-NR antiserum and antirabbit IgG 1:5000 conjugated to peroxidase. (b) Crude extract, $10 \mu \mathrm{g}$ protein subjected to PAGE in non-denaturing conditions. NR was localized on the nitrocellulose filter with the anti-NR antiserum and by the activity on the gel ( $\mathbf{\square})$.

Reduced methyl viologen : nitrate reductase activity was determined as above but using $0 \cdot 2$ mM-reduced methyl viologen instead of NADPH.

Preparation of anti-NR antiserum. NR was purified to homogeneity as described by Zauner \& Dellweg (1983). The antiserum was prepared following Bailey (1984). Approximately $40 \mu \mathrm{g}$ pure NR in $0.5 \mathrm{ml} 50 \%$ (v/v) Freund's complete adjuvant was injected subcutaneously, three times at two week intervals, to immunize male New Zealand white rabbits. The blood was collected three weeks after the last injection, and once clotted was centrifuged at $5000 \mathrm{~g}$ for $20 \mathrm{~min}$; the supernatant was divided into $0.5 \mathrm{ml}$ samples and stored at $-20^{\circ} \mathrm{C}$ until used as antiNR antiserum.
PAGE and Western blot. Extracts were made as described above with the addition of the following protease inhibitors: $0.25 \mathrm{mg} \mathrm{ml}^{-1}$ trypsin inhibitor, $0.1 \%$ apotrinin and $10 \mathrm{~mm}$-benzamidine. Both denaturing and non-denaturing PAGE were done as described by Smith (1987). Transfer of proteins to nitrocellulose membranes and immunodetection of NR were done as described by Winston (1987). Anti-NR antiserum diluted 1:2000 and antirabbit IgG diluted 1:5000 conjugated to peroxidase were used.

Determination of $N R$ activity in non-denaturing $P A G E$. The gel was cut into $2 \mathrm{~mm}$ sections, and NR activity was determined as indicated above with reduced methyl viologen as substrate.

Protein concentration was measured according to Bradford (1976). 


\section{Results}

Characterization of the antiserum raised against nitrate reductase

Titration of the anti-NR antiserum showed that the antiserum was able to inactivate NR (data not shown). The specificity of the antiserum was determined by Western blot, performing the electrophoresis in denaturing and non-denaturing conditions. A band of $52 \mathrm{kDa}$ corresponding to the NR subunits, along with other minor bands, was observed after electrophoresis in denaturing conditions (Fig. 1a). In samples subjected to non-denaturing PAGE, NR mobility was determined by activity and by Western blot. The same mobility was observed for the band detected by Western blot and by NR activity (Fig. $1 b$ ).

Nitrate reductase activity and protein in cells grown on different nitrogen and carbon sources

The levels of NR in Hansenula anomala, H. polymorpha and $H$. winge $i$ grown in different nitrogen and carbon sources are shown in Fig. 2. The cells were grown overnight at $30^{\circ} \mathrm{C}$ with shaking and harvested at midexponential phase. In our experimental conditions, the NR activity in $H$. anomala grown on nitrate was three times higher than that measured in the other species tested. NR activity was also consistently 2-4 times
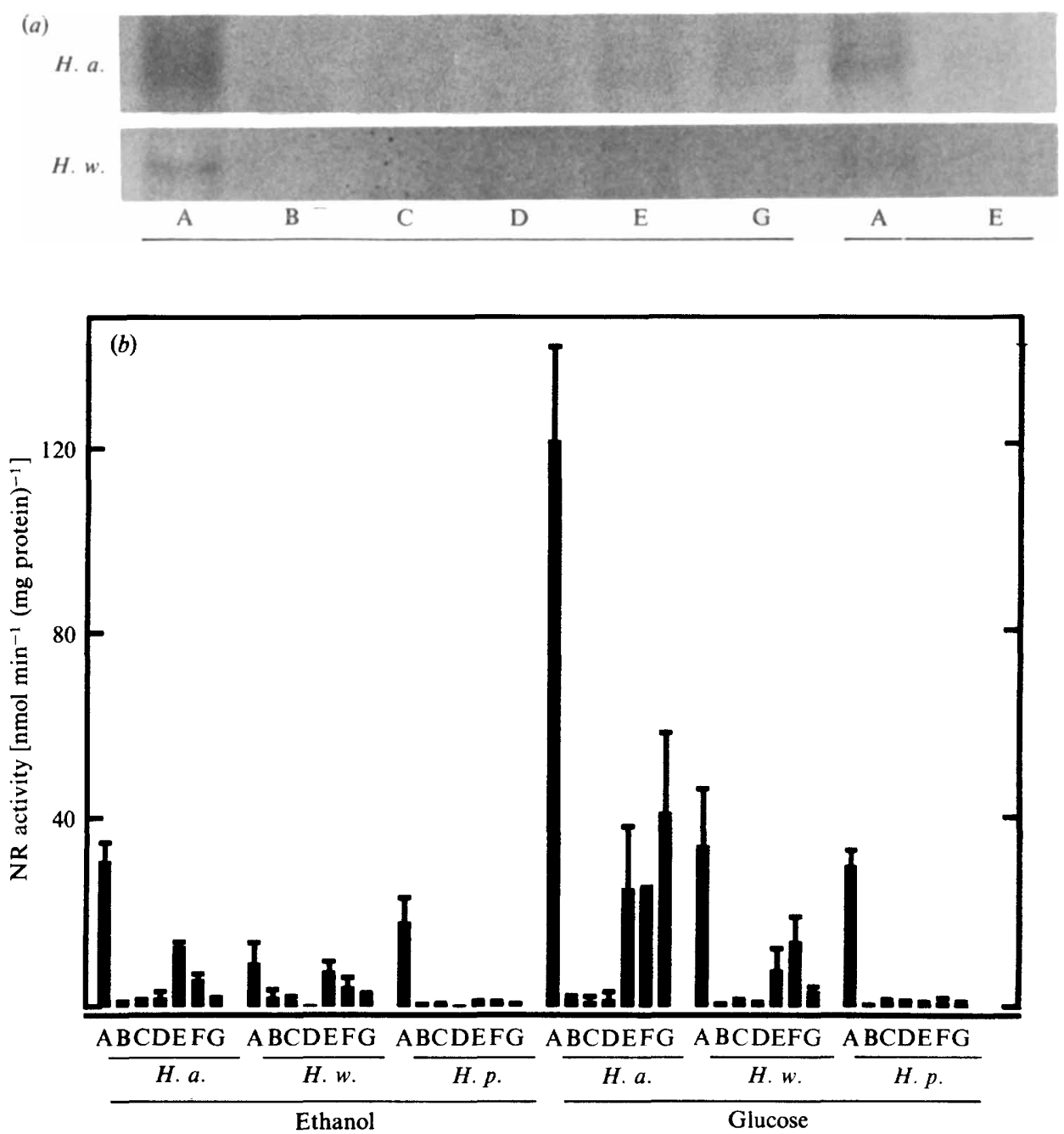

Fig. 2. Levels of NR protein and activity in H. anomala (H.a.), H. wingei (H.w.) and H.polymorpha (H.p.). Cells were grown in YNB and glucose or ethanol as carbon source and different nitrogen sources: (A) $50 \mathrm{~mm}$-nitrate, (B) $50 \mathrm{~mm}$-ammonium, (C) $25 \mathrm{~mm}$-glutamine, (D) $2 \%(\mathrm{w} / \mathrm{v})$ Bacto peptone (Difco), (E) $50 \mathrm{~mm}$-nitrate $+50 \mathrm{~mm}$-ammonium, (F) $50 \mathrm{~mm}$-nitrate $+50 \mathrm{~mm}$-glutamine and (G) $50 \mathrm{~mm}$ nitrate $+2 \%(\mathrm{w} / \mathrm{v})$ peptone. (a) Levels of NR protein in cells grown in glucose, determined by Western blot. Crude extract, $10 \mu \mathrm{g}$ protein, subjected to non-denaturing PAGE and transferred to nitrocellulose. (b) NR activity. Thin bars indicate SD ( $n=3)$, protein levels are from a single experiment. 

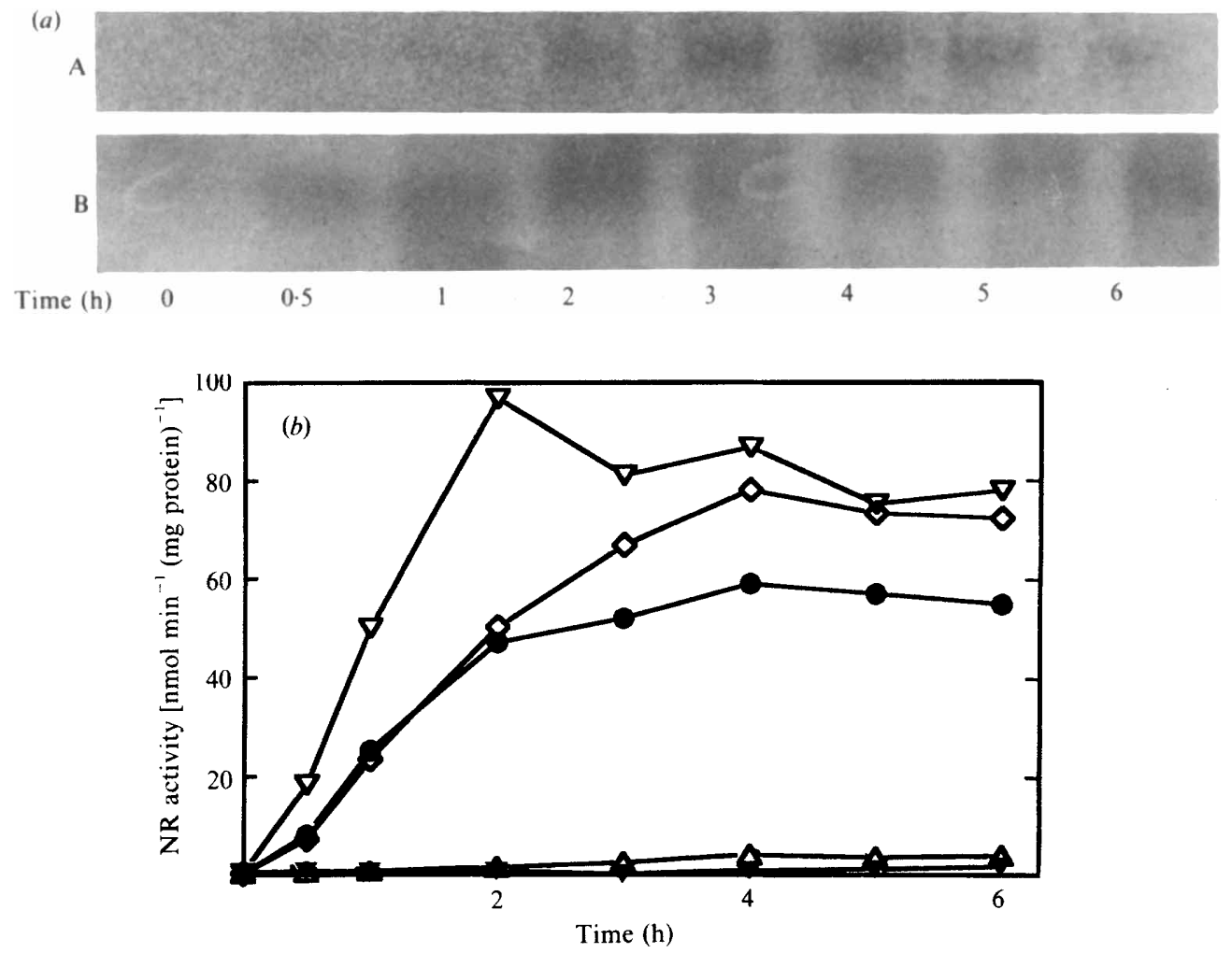

Fig. 3. Appearance of NR. Ammonium-grown $H$. anomala was resuspended at $10 \mathrm{mg} \mathrm{ml}^{-1}$ in YNB-glucose with different nitrogen sources. (a) Levels of NR protein in cells resuspended in (A) $50 \mathrm{~mm}$-nitrate or (B) $25 \mathrm{mM}$-glutamine $+50 \mathrm{~mm}$-nitrate determined by Western blot. Crude extract, $10 \mu \mathrm{g}(\mathrm{A})$ and $20 \mu \mathrm{g}$ (B) protein subjected to non-denaturing PAGE and transferred to nitrocellulose. (b) NR activity. Symbols: $\triangle$, nitrogen-free medium; $\nabla, 50 \mathrm{~mm}$-nitrate; $\diamond, 50 \mathrm{~mm}$-nitrate $+50 \mathrm{~mm}$-ammonium;, $50 \mathrm{~mm}$-nitrate $+25 \mathrm{~mm}$ glutamine; $\nabla, 50 \mathrm{mM}$-nitrate $+40 \mu \mathrm{g}$ cycloheximide $\mathrm{ml}^{-1}$. Experiments were repeated three times without significant differences; results shown are from a single experiment.

higher in cells grown on glucose than in ethanol-grown cells. When the yeasts were grown in nitrate-containing media in the presence of ammonium, glutamine or peptone, NR was only partially repressed. Levels of NR protein were determined in $H$. anomala and $H$. winge $i$ by Western blot. NR protein was not detected in cells grown in ammonium, glutamine or peptone (Fig. 2). A close correlation was observed between levels of NR activity and NR protein.

\section{Appearance of nitrate reductase}

In Fig. 3 the kinetics of appearance of NR activity in $H$. anomala, as well as the levels of NR protein under different conditions, are shown. Only nitrate was able to induce NR activity, and that ocurred even in the presence of $50 \mathrm{~mm}$-ammonium or $25 \mathrm{~mm}$-glutamine. In a nitrogen-free medium, NR activity was absent after $6 \mathrm{~h}$ incubation. The addition of $40 \mu \mathrm{g}$ cycloheximide $\mathrm{ml}^{-1}$ to nitrate-containing medium inhibited the appearance of NR activity. Levels of NR protein were always tightly correlated with NR activity. In $H$. wingei, nitrate from $10 \mathrm{~mm}$ in a medium containing $50 \mathrm{~mm}$-ammonium was able partially to induce NR (Fig. 4), in good agreement with the results shown in Fig. 2. Under the same experimental conditions, the levels of induction were much higher in $H$. anomala.

\section{Disappearance of nitrate reductase activity}

The disappearance of NR activity and NR protein under different conditions is shown in Fig. 5. The rates of disappearance of NR activity in nitrogen-free, nitrogenfree + cycloheximide, ammonium, ammonium + cycloheximide and glutamine media were all similar. However, in cells resuspended in nitrate + cycloheximide, the rate of NR activity disappearance was much lower than in the cases described above.

As expected from Fig. 2, in cells that were resuspended in a medium with ammonium + nitrate or glutamine + nitrate, NR activity only decreased to approximately $50 \%$ of the activity in cells resuspended in nitrate. Again, 


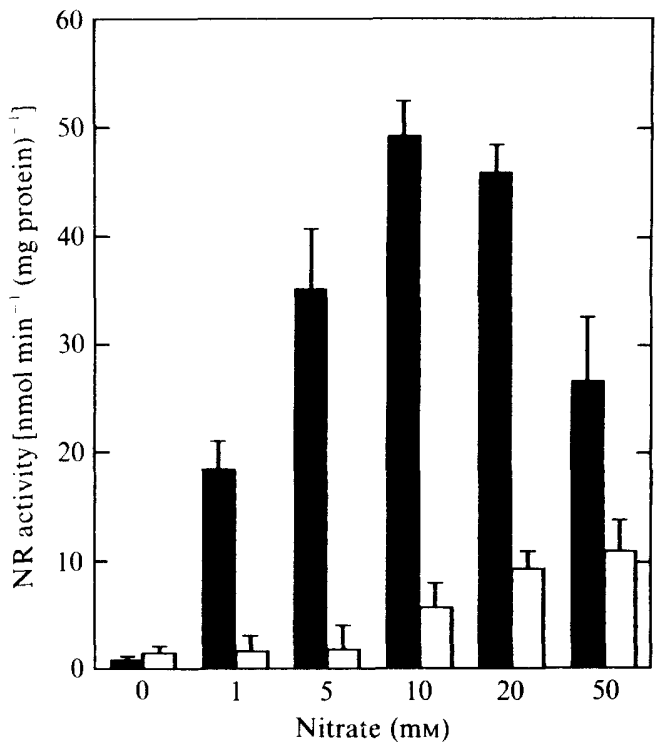

Fig. 4. Effect of nitrate concentration on appearance of NR in the presence of ammonium. Ammonium-grown $H$. anomala (filled bars) and $H$. wingei (open bars) were resuspended at $10 \mathrm{mg} \mathrm{m}^{-1}$ in medium containing $50 \mathrm{~mm}$-ammonium + different concentrations of nitrate. $\mathrm{NR}$ activity was determined $2 \mathrm{~h}$ after transfer. Thin bars indicate SD $(n=4)$.

Western blots showed that NR protein and activity were tightly correlated.

Nitrate-grown cells were washed and resuspended in ammonium medium until NR activity was reduced by $50 \%$. When transferred again to nitrate medium, with or without cycloheximide, they did not recover NR activity in the presence of cycloheximide (Fig. 6).

\section{Discussion}

In the yeasts studied in this work, $H$. anomala, $H$. wingei and $H$. polymorpha, neither NR protein, determined in $H$. anomala and $H$. wingei, nor NR activity was present in cells grown in ammonium, glutamine or peptone. However, NR was present in $H$. anomala, and $H$. winge $i$ incubated or grown in nitrate + ammonium, nitrate + glutamine and nitrate + peptone (Figs 2, 3 and 5). It can therefore be concluded that the nitrogen metabolite repression produced by ammonium or products of its assimilation is overcome by the inducing effect of nitrate. On the other hand, in these media no NR activity was detected in $H$. polymorpha. $H$. anomala showed NR activity only in the presence of nitrate, in contrast to Sporobolomyces roseus (Ali \& Hipkin, 1985) and Candida nitratophila (Ali \& Hipkin, 1986; Cannons et al., 1986) where NR was present in nitrogen-free medium.

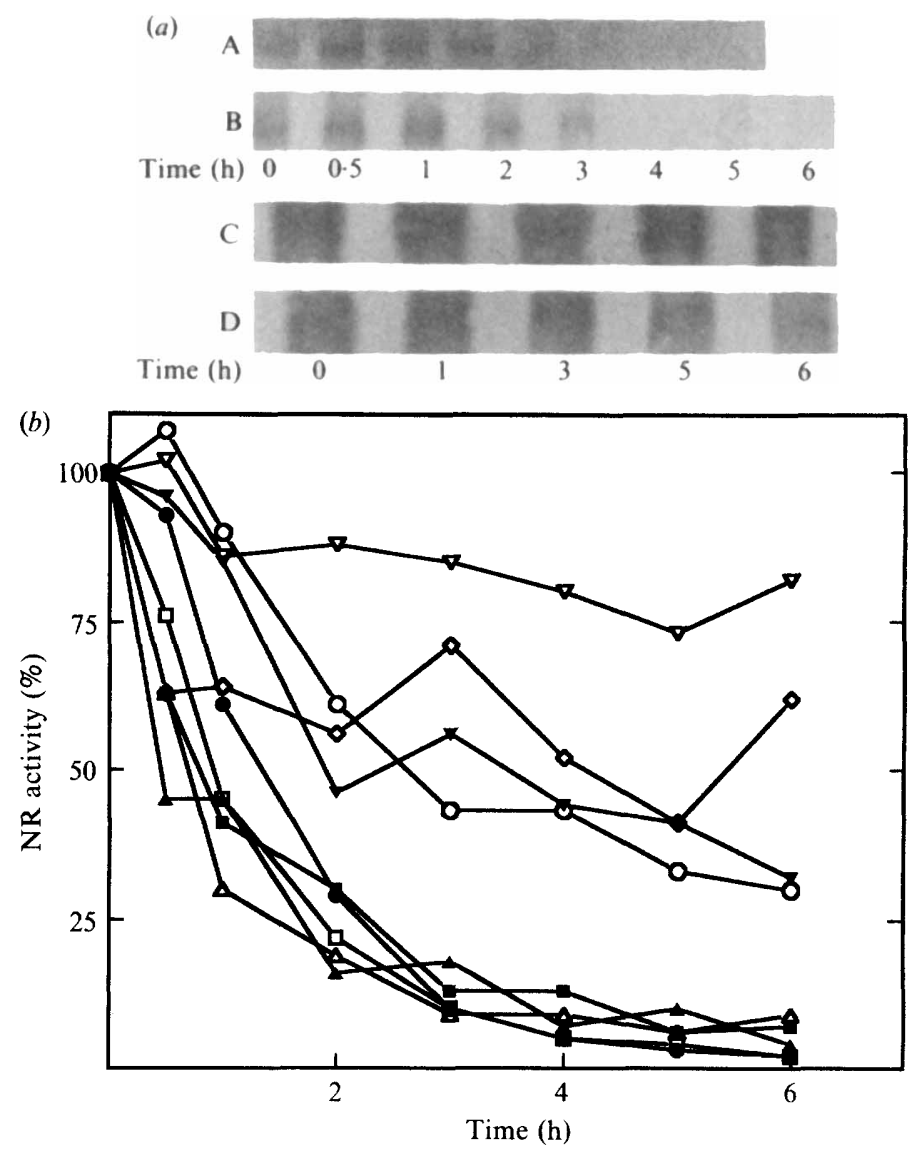

Fig. 5. Disappearance of NR. Nitrate-grown $H$. anomala was resuspended at $10 \mathrm{mg} \mathrm{ml}^{-1}$ in YNB-glucose with different nitrogen sources. (a) Levels of NR protein in cells resuspended in: A, ammonium; B, glutamine; , nitrate + ammonium; $D$, nitrate + glutamine. Crude extract (A, $10 \mu \mathrm{g} ; \mathrm{B}, \mathrm{C}, \mathrm{D}, 20 \mu \mathrm{g})$ was subjected to nondenaturing PAGE and transferred to nitrocellulose for Western blotting. (b) NR activity. Symbols: $\nabla, 50 \mathrm{~mm}$-nitrate; $\diamond, 50 \mathrm{~mm}$ nitrate $+50 \mathrm{~mm}$-ammonium $; \nabla, 50 \mathrm{~mm}$-nitrate $+40 \mu \mathrm{g}$ cycloheximide $\mathrm{ml}^{-1} . \square, 50 \mathrm{mM}$-ammonium; $\boldsymbol{\square}$, nitrogen-free medium; $\boldsymbol{\Delta}$, nitrogenfree medium $+40 \mu \mathrm{g}$ cycloheximide $\mathrm{ml}^{-1} ; \triangle, 50 \mathrm{~mm}$-ammonium $+40 \mu \mathrm{g}$ cycloheximide $\mathrm{ml}^{-1} ; \bullet, 25 \mathrm{~mm}$-glutamine; $\mathrm{O}, 25 \mathrm{~mm}$ glutamine $+50 \mathrm{~mm}$-nitrate. Experiments were repeated five times without significant differences; results shown are from a single experiment.

The levels of NR protein present under different conditons (Figs 2, 3 and 5) and the observed effect of cycloheximide on NR activity (Fig. 6) show that NR activity correlated with NR protein and that the appearance and disappearance of NR activity was associated with synthesis and loss of NR protein.

$H$. anomala, $\boldsymbol{H}$. wingei and $\boldsymbol{H}$. polymorpha grown in glucose possess levels of NR activity around 2-4 times higher than cells grown in ethanol (Fig. 2). These levels of induction are similar to those produced by glucose on the glycolytic enzymes in yeast (Maitra \& Lobo, 1971; Entian et al., 1984). 


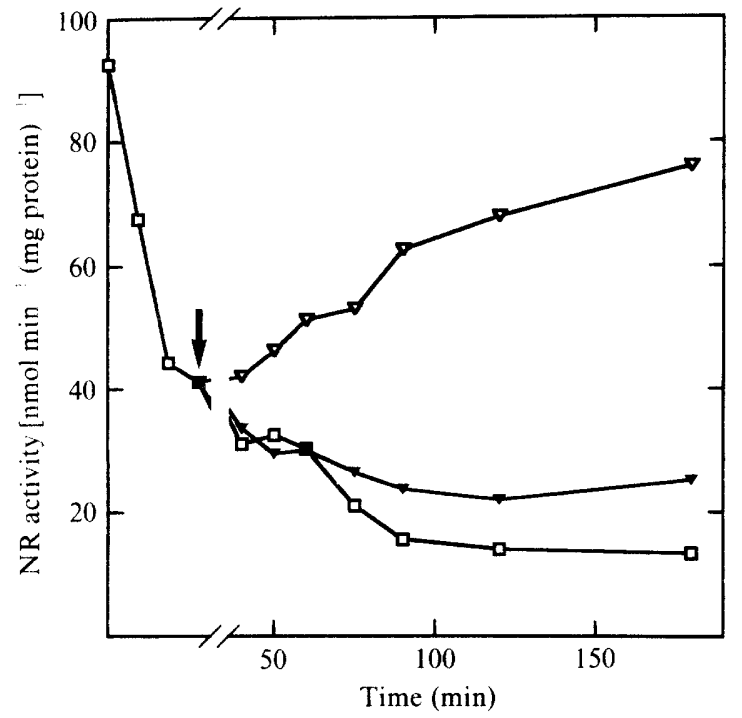

Fig. 6. Effect of cycloheximide on appearance of NR. Nitrate-grown $H$. anomala was resuspended at $10 \mathrm{mg} \mathrm{ml}^{-1}$ in YNB-glucose containing $50 \mathrm{~mm}$-ammonium ( $\square$ ) until NR activity reached approximately $50 \%$ of the initial level. At the time indicated (arrow) cells were washed with water (discontinuity in the scale) and transferred to YNB-glucose + ammonium and YNB-glucose $+50 \mathrm{~mm}$-nitrate with $(\boldsymbol{\nabla})$ or without ( $\nabla) 40 \mu \mathrm{g}$ cycloheximide $\mathrm{ml}^{-1}$. Experiments were repeated three times without significant differences; results shown are from a single experiment.

In $H$. anomala grown in nitrate and transferred to nitrate + cycloheximide, the rate of disappearance of NR activity was much lower than in cells transferred to nitrogen-free medium or nitrogen-free + cycloheximide (Fig. 5). Since cycloheximide suppresses synthesis of NR, these results suggest that nitrate improved the resistance of NR to proteolysis. Cycloheximide does not seem to inhibit any proteolytic system involved in the NR degradation, as in cells transferred to a nitrogen-free medium with or without cycloheximide, the rate of loss of NR activity was similar.

The characterization of the NR from $H$. anomala with the anti-NR antiserum by Western blot suggests a subunit mass of $52 \mathrm{kDa}$ in SDS-PAGE for the NR subunits, in accordance with Zauner \& Dellweg (1983). However, nitrate reductases from many other organisms, including yeast, have subunit masses of around $100 \mathrm{kDa}$ (Hipkin, 1989). In this work, subunits were prepared in the presence of protease inhibitors and the enzyme is active under non-denaturing conditions, and so $52 \mathrm{kDa}$ seems to be the true mass of NR subunits of $H$. anomala. Cloning of the NR gene from $H$. anomala will be necessary to resolve this problem definitively.

In contrast to the results reported here for $H$. winge $i$ (Fig. 4), Jones et al. (1989) reported that ammonium or glutamine prevented the induction by nitrate of NR. They also reported levels of NR activity twice as high as those obtained in this work. These differences could be due to the strain used, as well as to the methods.

In conclusion, the results obtained here, along with those already reported (Hipkin, 1989), show that in yeast no inactive NR is present in ammonium-, glutamine- or peptone-grown cells. This contrasts with observations in algae and plants (Funkhouser et al., 1980; Funkhouser \& Ramadoss, 1980; Oaks et al., 1988). On the other hand, the appearance and disappearance of NR is tightly correlated with the synthesis and loss of NR protein. This process, in $H$. anomala, is mainly regulated by nitrate, with less participation from nitrogen metabolite repression.

We thank Dr C. Gancedo (I.I.B., C.S.I.C. Madrid) for his criticisms and encouragement and Dr L. Rodriguez for many fruitful discussions. We also thank Drs M. A. Falcon and A. Carnicero for advice during the preparation of antiserum and $\mathbf{J}$. Siverio and $\mathbf{M}$. Expósito for caring for the animals. The spectrophotometer used was a donation from the Alexander von Humboldt Foundation (Bonn, Germany) to J.M.S. C. G. was partially supported by the Cabildo Insular de Tenerife. This work was supported by grants $9 / 31.7 .89$ and 29/8.3.90 from the Gobierno de Canarias.

\section{References}

Ali, A. H. \& Hipkin, C. R. (1985). Nitrate assimilation in the basidiomycete yeast Sporobolomyces roseus. Journal of General Microbiology 131, 1867-1874.

Ali, A. H. \& HiPKIN, C. R. (1986). Nitrate assimilation in Candida nitratophila and other yeasts. Archives of Microbiology 144, 263-267.

BAILEY, G. S. (1984). The production of antisera. In Methods in Molecular Biology, vol. 1, pp. 295-300. Edited by J. M. Walker. Clifton, New Jersey: Humanana Press.

Barnett, J. A., PaYne, R. W. \& Yarrow, D. (1984). Yeasts Characteristics and Identification. Cambridge : Cambridge University Press.

BRADFORD, M. M. (1976). A rapid and sensitive method for the quantitation of microgram quantities of protein utilizing the principle of protein-dye binding. Analytical Biochemistry $\mathbf{7 2}$. 248-254.

Cannons, A., Ali, A. H. \& Hipkin, C. R. (1986). Regulation of nitrate reductase synthesis in the yeast Candida nitratophila. Journal of General Microbiology 132, 2005-2011.

DunN-Coleman, N. S., Smarrell, J., JR \& Garret, R. H. (1984). Nitrate assimilation in eukaryotic cells. International Review of Cytology, 92, 1-50.

Entian, K.-D., Fröhlich, K.-U. \& MECKe, D. (1984). Regulation of enzymes of carbohydrate metabolism in the yeast Saccharomyces cerevisiae. Biochimica et Biophysica Acta 799, 181-186.

Funkhouser, E. A. \& Ramadoss, C. S. (1980). Synthesis of nitrate reductase in Chlorella. II. Evidence for synthesis in ammoniumgrown cells. Plant Physiology 65, 944-948.

Funkhouser, E. A., Shen, T.-C. \& Akerman, R. (1980). Synthesis of nitrate reductase in Chlorella. I. Evidence for a inactive precursor. Plant Physiology 65, 939-943.

HIPKIN, C. R. (1989). Nitrate assimilation in yeast. In Moíecular and Genetic Aspects of Nitrate Assimilation, pp. 51-68. Edited by J. L. Wray and J. R. Kinghorn. Oxford: Oxford University Press.

Jones, C. P., WRAY, J. L. \& KinghorN, J. R. (1987). The role of nitrogen sources in the regulation of nitrate reductase and nitrite reductase levels in the yeast Hansenula wingei. Journal of General Microbiology 133, 2767-2772. 
Maitra, P. K. \& LoBo, Z. (1971). A kinetic study of glycolytic enzyme synthesis in yeast. Journal of Biological Chemistry 246, 489-499.

Oaks, A., Poulle, M., Goodfellow, V. J., Cass, L. A. \& Deising, H. (1988). The role of nitrate and ammonium ions and light on the induction of nitrate reductase in maize leaves. Plant Physiology 88, $1067-1072$

Pateman, J. A. \& KinghoRn, J. R. (1976). Nitrogen metabolism. In The Filamentous Fungi, vol. 2, pp. 159-237. Edited by J. E. Smith and D. R. Berry. London: Edward Arnold.

SмIтH, J. A. (1987). One-dimensional gel electrophoresis of proteins. In Current Protocols in Molecular Biology, pp. 10.2.1-10.2.9. Edited by F. M. Ausubel, R. Brent, R. E. Kingston, D. O. Moore, J. G. Seidman, J. A. Smith and K. Struhl. New York: John Wiley and Sons.
SNELl, F. D. \& SNELl, C. T. (1949). Colorimetric Methods of Analysis, 3rd edn, pp. 804-805. New York: Van Nostrand.

WraY, J. L. \& Kinghorn, J. R. (eds) (1989). Molecular and Genetic Aspects of Nitrate Assimilation. Oxford: Oxford University Press.

Winston, S. E., Fuller, S. A. \& Hurrel, J. G. R. (1987). Western Blotting. In Current Protocols in Molecular Biology, pp. 10.8.1-10.8.6. Edited by F. M. Ausubel, R. Brent, R. E. Kingston, D. D. Moore. J. G. Seidman, J. A. Smith and K. Struhl. New York: John Wiley and Sons.

Zauner, E. \& Dellweg, H. (1983). Purification and properties of the assimilatory nitrate reductase from the yeast Hansenula anomala. European Journal of Applied Microbiology and Biotechnology 17, 90-95. 